\title{
KRAS NP_004976.2:p.G12D
}

National Cancer Institute

\section{Source}

National Cancer Institute. KRAS NP 004976.2:p.G12D. NCI Thesaurus. Code C98369.

A change in the amino acid residue at position 12 in the GT Pase KRas protein where

glycine has been replaced by aspartic acid. 